\title{
DETERMINANTS OF EARNINGS MANAGEMENT: THE STUDY OF NIGERIAN NONFINANCIAL COMPANIES
}

\author{
Ochuko Benedict Emudainohwo* \\ Delta State University, Faculty of the Social Sciences, Department of Accounting and Finance, \\ Abraka, Nigeria
}

The extant literature links manageress incentives to earnings management. It has globally accounted for the collapse of some well-known, established firms, since it depicts a low financial reporting quality. This study employed data from the 77 nonfinancial firms listed on the Nigerian Stock Exchange for the period 2013-2019 in order to examine the determinants of earnings management. The result showed strong evidence of an incentive to manage earnings. Profitability (Return on Assets - ROA) and the size of a firm have a strong positive impact on earnings management, while the non-debt tax shield and operating cash flows have a strong negative influence on earnings management. The study suggests that external stakeholders should observe a firm's factors influencing its assets, non-debt tax shield and operating cash flows (such as accelerating/delaying cash receipts/payment through the use of credit sales and granting discounts), these being the crucial factors influencing earnings management even when the firm is increasing in size. Management should minimally use the above-mentioned factors of a firm as an earnings management instrument.

Keywords: earnings management, nonfinancial firms, Nigerian Stock Exchange, stock returns

JEL Classification: G14, M41

\section{INTRODUCTION}

Earnings management uses acceptable accounting rules and procedures, as well as evading business practices, in order to achieve desired ends. It is a form of a financial report designed by management, presented so as to obtain a private gain of some

* Correspondence to: O. B. Emudainohwo, Delta State University, Faculty of the Social Sciences, Department of Accounting and Finance, Abraka, Nigeria; e-mail: ochuko.bemudainohwo@gmail.com kind. There are two basic motives: opportunistic and efficient motives. Opportunistic motives are those implying that managers use their decisions to maximize their personal gains. In efficient motives, manageress window-dress a financial report so as to signal information to the users of the report (Cudia \& Dela Cruz, 2018, 120). The implication of both motives is that management do not present the firm's true economic position (Emudainohwo, 2020, 397). Rather, they mislead stakeholders, as well as prospective investors, by signaling false information about the firm's performance as if it were true (Beaver, 2002, 468). 
Earnings management practically violates the two primary qualities of the usefulness of a financial report for decision-making, as outlined in the Statement of Financial Accounting Concepts No. 2 (FASB, 2008), these two qualities being the relevance and reliability of the characteristics of information that make accounting information useful. Relevance, on the one hand, implies that the information contained therein will make a difference in arriving at a decision, and reliability, on the other, implies an expectation that financial information users' decisions are founded on good judgement based on trusted information. Thus, the earnings management strategy erodes the quality of a financial report.

Although there are authors who considered that earnings management was a reasonable and legal option to enhance the position of a firm, it can be dubiously employed (Osemene, Adeyele \& Adinnu, 2018 , 210). The processes involved in earnings management can be detrimental to stakeholders given a lack of transparency and the reduced reliability of reports. Thus, it broadens the information asymmetry gap to the users of financial reports. For the largest part, firms put the blame for earnings-managementrelated issues on the error and misinterpretation of reporting rules. Intentional collusions toward management incentives, however, are the reasons for that. Earnings management is a matter for stakeholders to be concerned about, because the institutional environment and corporate governance have not provided better legal protection and control restricting managers' actions.

Some factors driving managers' incentives to manage earnings are examined against said backdrop in the study. Focusing on Nigeria in this study is due to the fact that it is the most populous West African country, which boosts a large developing capital market, the biggest African economy and the $27^{\text {th }}$ largest economy in the world in terms of the GDP and has industrialization potentials in terms of human capital and resources (World Economic Forum, 2020). Furthermore, Nigeria instituted a new corporate governance code in 2003 and another in 2011 so as to minimize persisting corporate governance challenges.
Consistently with prior studies, earnings management (the dependent variable) is proxied with discretionary accruals following the modified Jones model (Dechow, Sloans \& Sweeney, 1995, 199) for this study. The independent variables (Table 1) are those variables that earlier studies have shown to exert an influence on managers' incentives for earnings management. The Heteroskedasticity Cross-Panel Feasible Generalised Least Squares (FGLS) model was used to analyze the objective of the study. The study found that profitability (ROA) and the firm size have a significant positive association with earnings management, whereas the non-debt tax shield and operating cash flows have a significant negative bearing on earnings management. The study contributes to the better understanding of earnings management in a developing economy, and perhaps to guiding investment decisions. The rest of the paper is organized as follows: in Section 2, the theoretical and empirical reviews are presented; Section 3 discusses the material and the method; Section 4 is the presentation of the results obtained in the study and discussion, while a conclusion is finally given in Section 5.

\section{THEORETICAL AND EMPIRICAL REVIEWS}

Signaling and agency theories are adopted in order to explain the research problems of the study. Signaling theory assumes that information is neither made freely nor is it equally available to economic agents. This results in an information asymmetry gap among managers and stakeholders. In the context of information, managers are the most informed and they have privileged information about the economic situation of the firm. Being privileged to know that information about the economic standing of the firm, managers can employ earnings management schemes so as to influence the quantity/quality and type of the information they want to signal to the different stakeholders who depend on the financial statement report of the firm for decision-making. By doing so, managers may choose to either reduce or increase such communicated information which may mislead or assist the user of the report, which may lead to a 
challenging adverse selection situation prospective investors may be faced with.

On the other hand, agency theory is founded on the divergence of the interest and available information between managers and the owners of the firm, which assumes that managers' personal interests affect their decisions and activities. This influences them to seek to maximize their interest to the detriment of the interest of the owners of the firm. In order to manage this conflict, one of the owner's initiative is to motivate managers by compensating them proportionally to their performance. This creates a relationship between the managers' achievement and the compensation. This relationship is turned into an incentive to manage earnings upwards for a better remuneration. This implies that the information asymmetry gap is broadened between the manager and the owners of the firm when scheming earnings management.

\section{The probability of bankruptcy and earnings management}

Bankruptcy is when the profit-making power of a firm is reduced, and the probability of paying back a debt has fallen (Altman, 2013, 429). It is the probability that a firm will go into default. The bankruptcy of firms may probably cause huge economic and social losses to their stakeholders and/or may lead to an inefficient allocation of capital (Kumar \& Ravi, 2007). Although cost reduction is a normal efficiency practice, not earnings management per se, firms facing bankruptcy are more likely to reduce certain costs when in financial distress (Hassanpour \& Ardakani, 2017, 216-217). In the future, distressed companies would not be able to fulfil their obligations (Ghazali, Shafie \& Sanusi 2015, 195), which may lead to filing for bankruptcy or reorganization. Such companies have a probability of bankruptcy and prefer making more accounting changes than the companies that are less likely to go bankrupt (Ghazali et al, 2015, 195).

I. Lisboa $(2019,80)$ showed that distressed firms engaged in earnings management. S. Hassanpour and M. N. Ardakani (2017, 217-218) examined the effect of prebankruptcy financial distress on earnings management for the firms listed on the Tehran Stock Exchange during the period 2010-2014 and found a significant positive relationship between prebankruptcy financial distress and earnings management. M. Bisogno and R. De Luca $(2015,47)$ examined the relationship between financial distress and earnings management practices in the economic context of family-owned firms for Italian not publicly listed SMEs. They showed that firms manipulated their financial statement so as to portray the better financial performances that would enable them secure external funding. While examining the evidence of earnings management in distressed firms during the period prior to filing for bankruptcy, A. Dutzi and B. Rausch $(2016,15)$ showed that firms engaged in earnings management prior to the bankruptcy event. However, N. A. Shabani and S. Sofian $(2018,162)$ found a negatively significant relationship between earnings smoothing and bankruptcy risk. The study aligned with the statement that firms manipulated earnings when they were faced with the likelihood of bankruptcy and the hypothesis that:

H1: The probability of bankruptcies has a significant positive impact on earnings management.

\section{Profit and earnings management}

Profit is an important goal of financial management. It is a determinant of business, as well as management performance, in the short run and potentially in the long run (Cudia \& Dela Cruz, 2018, 119). It is the bottom-line item of the income statement that presents value added, financial benefits and an economic situation of an entity, which is a yardstick for analyzing the expected future performance of the firm by market dealers (Anjum, Saif, Malik \& Hassan, 2012, 14). Managers are tempted to manipulate profits through exercising an accounting choice and judgment when providing relevant information to stakeholders (Cudia \& Dela Cruz, 2018, 119). For instance, management may manipulate earnings by declaring not too high (low) income trend or a flat income trend over years (Beaver, 2002, 466; Ghazali et al, 2015, 198). Downward earnings management 
may imply avoiding paying a huge tax or government scrutiny (Lisboa, 2019, 72). Additionally, the weak performances of a firm provide an incentive to engage itself in upward earnings management intended to attract investors.

Some earlier study showed that profitability was negatively related to earnings management (Cudia \& Dela Cruz, 2018, 127). H. Anjum et al (2012, 17) examined the impact of earnings management on the profitability of the nonfinancial firms listed on the Karachi Stock Exchange and found that earnings management had a negative impact on the profitability of firms. A. W. Ghazali et al $(2015,190)$ showed that the managers of a firm would engage themselves in earnings management when they are financially healthy and make a high profit, on the example of a sample of Malaysian publicly listed companies from the year 2010 to the year 2012. It probably suggests that a high profit should be manipulated downward in order to avoid paying high taxes. M. A. Abu-Jebbeh and A. Al-Thuneibat $(2017,259)$ shows that profitability exerts a significant impact on earnings management, which they prove in a study of the 40 industrial firms listed on the Amman Stock Exchange over the period 2009-2013. The study proxies profitability with return on assets, which shows how efficient an organization is with its assets, and hypothesizes that:

H2: Profitability (ROA) has a significant positive effect on earnings management.

\section{The non-debt tax shield and earnings management}

Non-debt tax shields arise from allowable deductions before taxes for items as as depreciation, amortization, provision for bad debts, investment tax credits and loss carryforwards (Clemente-Almendros \& SogorbMira, 2018, 165). Managers will prefer non-debt taxshield instruments over debt tax shield instruments for earnings management because of incentives to permanently defer or avoid taxes and because there are no debt covenant restrictions (ClementeAlmendroa \& Sogorb-Mira, 2018, 165). It is less costly when compared to using the debt instruments that require costly interest payments and reduces cash outlays. As an earnings management instrument, the non-debt tax-shield option takes the form of either charging a higher non-debt tax-shield transaction to report lower earnings or a lower non-debt tax-shield transaction to report higher earnings. S. O. Rego and R. Wilson $(2012,778)$, however, argued against the use of a non-debt tax shield as an earnings management instrument. They opined that aggressive tax strategies had significant uncertainties and a highcost implication from the tax authority where its use violates the tax policy.

Furthermore, the International Financial Reporting Standards (IFRS) require foreign subsidiaries to consolidate under the parent company (IFRS 10, 2011) in certain circumstances, but the earnings coming from such subsidiaries are not recognized as taxable income until they are transferred to the parent company. Consequently, companies may permanently defer income taxes through reinvestment abroad, which is a non-debt tax-shield strategy (ClementeAlmendros \& Sogorb-Mira, 2018, 165). Due to agency conflict between managers and owners, the opportunistic managers seeking to maximize their self-gain resort to tax-avoidance schemes to direct rent to themselves (Desai \& Dharmaphala, 2009). However, managers will not engage themselves in tax avoidance if it is not gainful to them (Amidu \& Yorke, 2017). This will force a negative relationship between a non-debt tax shield and earnings management.

M. Amidu, S. M. Yorke and S. Harvey (2016, 141) found a positive relationship between company tax avoidance and earnings management. S. D. Dyreng, M. Hanlon and E. L. Maydew (2010, 1185) show that management play a significant role in determining the level of the tax avoidances undertaken by a firm. The study assumes that a manager's personal interest is an incentive for them to manipulate the use of the non-debt tax-shield option, and the hypothesis that:

H3: A non-debt tax shield has a significant positive influence on earnings management. 


\section{Operating cashflows and earnings management}

Operating cashflows are cashflows mainly from a firm's major producing activities, such as cash received from customers and cash paid to suppliers and employees. It is argued that the firms that experience low operating cashflows are more likely to initiate earnings management in order to increase the cashflow from operating activities, such as accelerating cash collection (Andreas, 2017; Jang \& Kim, 2017, 330). On the other hand, the firms with high operating cashflows would not mind so much granting credit sales as much as it is profitable to do so (Cudia \& Dela Cruz, 2018, 121-122). Also, firms may leverage on access to cheap sources of finance and delay the cash collection period. Managers can influence the realization of the timing of cashflows by accelerating or delaying sales receipts and cash payments to some extent (El-Diri, 2018, 8).

In an earlier study, C. S. F. Hastuti M. Arfan and Y. Diantimala $(2018,1141)$ tested the influence of cashflows from operation for the manufacturing firms listed on the Indonesian Stock Exchange and found that cashflows from operation have a negatively significant relationship with earnings management. On the other hand, C. P. Cudia and A. L. C. Dela Cruz (2018, 126-127) showed that cashflows from operation are positively and significantly related to earnings management. B. Banimahd and M. J. Aliabadi (2013, 1681) examined the impact of earnings management on the management of cashflows from operating activities over the period from 2004 to 2011 for the firms listed on the Tehran Stock Exchange and found a significant relationship between them.

Furthermore, free cash theory argued that managers would often use excess cash flows for the investments that would maximize their own wealth, rather than that of the owner of the firm (Harbula, 2001, 491). S. L. Chalak and S. Mohammadnezhad (2012, 435) supported free cash theory when he found that firms with a high level of cash flows and low growth are the typical firms that engaged themselves in earnings management. Given the fact that cash is the 'lifeblood' for the activities carried out by a firm, the study opines that managers manipulate cash flows and hypothesizes that:

H4: Operating cashflows have a significant positive influence on earnings management.

\section{Stock returns and earnings management}

Stock returns is a powerful evaluator of the value of a firm. It takes into consideration capital gains and dividends, by which return on investors' stock ownership is measured. Stock value will always change as the fundamentals of a firm are revealed over time. A drop in the stock price is undesirable from the point of view of management since stock returns remain one of the primary objectives for evaluating management performance, and their compensation is particularly tied to it (Ali, Noor, Khurshid \& Mahmood, 2015). Hence, mangers undertake earnings management so as to influence the investor's positive reflection of the performance of a firm. Their job security and their value in the labor market increase with better stock returns (Chi \& Gupta, 2009, 1656).

Although there are incentives for managers to manipulate the accounting numbers that will influence the stock price of a firm, the stock price is not determined by management, but in the stock market by market dealers instead. Therefore, through earnings management, managers make investors perceive a better situation of the firm that encourages them to pay a higher price for it. Thus, a dealer's perception of earnings as good (bad) news will reflect upward (downward) the stock price and, eventually, stock returns (Darmawan, Sutrisno \& Mardiati, 2019, 8). The higher the surprise of the unexpected news, the more significant the market reaction that alters the stock price equilibrium (Sayari, Mraihi, Finet \& Omri, 2013, 52). Given the fact that managers are led to maximize their financial report policy in order to present it to the market, the most successful image exploiting the insufficiency of accounting standards, managers manipulate investors' thinking and expectations in order to exert an influence on the stock price and stock returns. It is in this light that the signaling theory based on earnings management is considered as a financial communication tool. 
S. Sayari et al $(2013,51)$ showed that earnings management had positive bearings on stock returns in Tunisia. M. Bansal, A. Ali and B. Choudhary (2021) investigated the real bearing of earnings management on the cross-sectional stock return of the weekly and monthly data of 3,085 firms of the Bombay Stock Exchange from January 2000-December 2019 and showed that investors discounted the stock price when they perceived low-quality real earnings management.

J. D. Chi and M. Gupta (2009) posits that low-quality earnings management relates to lower future abnormal stock returns, finding that the firms with low-quality earnings management underperformed those with high-quality earnings management. Lowquality earnings management translates into lower future operating performances.

A. A. Al Saedi $(2018$, 9) found no significant relationship between earnings management and stock returns by examining the relationship between earnings management practice and stock returns on the shares of the Qatari industrial listed firms over the period 2009-2017. A. M. Al Omush, W. M. Masadeh and R. M. Zahran $(2019,20)$ examined the impact of earnings management on the stock returns of the firms listed on the Amman Stock Exchange on a sample of 18 firms over the period 2014-2018. The study found no relationship between the variables, suggesting that the stock exchange was not able to reflect earnings management practices. N. Nuryaman $(2013,73)$ reported that earnings management had a negative bearing on stock returns from the analysis of the effects of earnings management on the stock returns of firms, with the quality of audit as the moderating variable for the 149 manufacturing firms listed on the Indonesian Stock Exchange in 2010. The study hypothesizes that:

H5: Stock returns have a significant negative bearing on earnings management.

\section{The firm size and earnings management}

Two different points of view are presented of the relationship between the firm size and earnings management. The one argument is that, as firms become larger and more successful, there is the tendency for them to expose themselves to the risk of the scrutiny of a Government agency and pressure from the capital market (Young, 1999; Dechow, Ge \& Schrand, 2010, 380; Ali et al, 2015, 48). To avoid scrutiny implications, if any, management employs earnings management so as to cover up (Dechow et al, 2010, 380; Lusi \& Swastika, 2013, 79). Larger firms are also likely to be engaged in earnings management when placing seasoned equity offerings in order to signal better information to prospective buyers. The above argument attracts a positive relationship between the firm size and earnings management.

Contrarily, large firms are assumed to engage themselves less on earnings management given the effectiveness of their employees' competences and their capacity to contract competent external audit and/or the audit committee that limits the activities of earnings management, which depicts a negative relationship. Furthermore, it is argued that smaller firms are more likely to have a weak internal control structure compared to larger firms with strong internal control and the highly qualified auditors who know how to avoid earnings management (Lusi \& Swastika, 2013, 78-79). As a result, smaller firms are more likely to make up and correct misstatements in previously reported earnings.

I. Lisboa $(2019,80)$ found that the firm size was statistically significant to explain why firms engage themselves in earnings management. O. D. Moses $(1987,358)$ and S. Hefferman, M. F. Xiaoqing and F. Xiaolan $(2008,13)$ showed that the firm size was positively related to the quality of earnings. J. Gordanlidavaji and H. Vakilifard (2014, 519), U. Ali et al (2015) and U. Uwuigbe, U. O. Ranti and O. Bernard $(2015,224)$ showed that the firm size had a significant positive influence on earnings management. Contrarily, C. S. F. Hastuti et al (2018, 1141) examined the relationship between the firm size and earnings management for the manufacturing firms listed on the Indonesian Stock Exchange. They found a negative weak relationship between them. The study posits that as the firm size increases, the volume of the activities carried out by the firm opens 
diverse opportunities to manipulate earnings, and hypothesizes that:

H6: The size of a firm has significant positive bearings on earnings management.

\section{Growth and earnings management}

Growth depicts many situations in a firm, such as increasing revenue and the volume of production, the emergence of new units, an increase in assets per worker, and so forth. Substantiable growth for firms is needed to maximize their shareholders' wealth, which does mean growth is a necessity for firms. It is posited that high-growth firms are more likely to engage themselves in earnings management so as to maintain the stream of earnings (Lee, Li \& Yue, $2006,330)$ and avoid unfavorable market reactions to reporting poor earnings. Negative growth is likely to attract market attention.

Additionally, managers are cautious while disclosing earnings, knowing that the earnings indicator will eventually signal the probable growth of the firm's earnings. They try to minimize growth signals by managing the earnings report in a way to portray the picture as per their incentives (Anjum et al, 2012, 14) in order to avoid scrutiny.

M. F. McNichols $(2000,315)$ showed that the firms expecting a greater growth of earnings were more likely to engage themselves in earnings management than the firms facing less expectant growth. B. Alareeni (2018) stated that the higher the growth rate, the lesser the need to manage earnings, and vice versa. In other words, a strong growth opportunity overshadows earnings management forcing a negative relationship (Al Saedi, 2018). J. D. Kwarbai, R. I. Akintoye, F. F. Adegbie and A. N. Nwaobia (2019, 1) showed that growth opportunities had a significant positive effect on earnings management. B. Alareeni (2018) showed that the higher the growth rate, the lesser the need to manage earnings, and vice versa. The study posits that a growth prospect will influence earnings management upward or downward, thus hypothesizing that:
H7: Growth is significantly positively related to earnings management.

\section{MATERIAL AND METHODS}

In the study, the secondary data retrieved from the annual financial report for the 77 sampled nonfinancial firms listed on the Nigerian Stock Exchange (NSE) from 2013-2019 (539 company-years) were used. As the dependent variable of the study, earning management is proxy with discretionary accruals separated from total accruals based on the modified Jones model (Dechow et al, 1995, 199). Table 1 presents the proxy and measurement of the variables.

\section{Discretionary accruals estimation}

The modified Jones model (Dechow et al, 1995, 199) was employed to separate the discretionary and nondiscretionary accruals as follows.

Total accruals are:

$$
T A_{i . t}=\left(\Delta C A_{i . t}-\Delta C a s h_{i . t}\right)-\left(\Delta C L_{i . t}-\Delta C L S T D_{i . t}\right)-D E P_{i . t}
$$

where for the firm $i$ in the year $t$ :

$T A_{i . t}$ is the total accruals, $\Delta C A_{i . t}$ is a change in the current assets, $\triangle$ Cash $_{i, t}$ is a change in cash and the cash equivalent, $C L_{i . t}$ is a change in the current liabilities, $\triangle C L S T D_{i . t}$ is a change in the short-term debt included in the current liabilities, and $D E P_{i . t}$ is the expenses of depreciation and amortization.

The modified Jones model (Dechow et al, 1995, 199) reads as follows:

$$
\begin{aligned}
\frac{T A_{i, t}}{A_{i, t-1}}= & \alpha_{0}\left(\frac{1}{A_{i, t-1}}\right)+\alpha_{1} \frac{\left(\Delta \operatorname{Rev}_{i, t-1}-\Delta \operatorname{Rec}_{i, t-1}\right)}{A_{i, t-1}} \\
& +\alpha_{2} \frac{P P E_{i, t}}{A_{i, t-1}}+\varepsilon_{i, t}
\end{aligned}
$$

where for the firm $i$ in the year $t, \Delta R e v_{i, t-1}$ is the revenue in the year $t$ minus the revenue in the year $t-1, \Delta \operatorname{Rec}_{i, t-1}$ is the receivable in the year $t$ minus the receivable in the year $t-1, P P E_{i, t}$ is the gross property, 
Table 1 The proxy, measurement and source of the variables for the analysis

\begin{tabular}{|c|c|c|c|}
\hline Variables & Proxy & Measurement & Data Sources \\
\hline $\begin{array}{l}\text { Earnings } \\
\text { management }\end{array}$ & $\begin{array}{l}\text { Discretionary } \\
\text { accruals }\end{array}$ & $\begin{array}{l}\text { Modified Jones model (Dechow et al., } 1995 \text {, } \\
\text { 199): see equations (1) to (4) }\end{array}$ & Annual financial statement \\
\hline $\begin{array}{l}\text { Probability of } \\
\text { bankruptcy }\end{array}$ & $\begin{array}{l}\text { Measure of } \\
\text { financial distress }\end{array}$ & $\begin{array}{l}\text { Altman's z score (Altman, 2013, 431-432): see } \\
\text { equation ( } 5 \text { ) }\end{array}$ & Annual financial statement \\
\hline Profitability & $\begin{array}{l}\text { Return on assets } \\
\text { (ROA) }\end{array}$ & $\frac{\text { income before extraordinary items }}{\text { total assets }}$ & Annual financial statement \\
\hline $\begin{array}{l}\text { The non-debt tax } \\
\text { shield }\end{array}$ & $\begin{array}{l}\text { Tax allowable } \\
\text { deductions. }\end{array}$ & $\frac{\text { Depr }+ \text { Amort. }+R \& D}{\text { total assets }}$ & Annual financial statement \\
\hline $\begin{array}{l}\text { Operating } \\
\text { cashflows (OCF) }\end{array}$ & OCF & OCF scaled down* by $1,000,000$ & Annual financial statement \\
\hline Stock returns & Stock returns & $\frac{\left(\text { stock price }_{t}-\text { stock price }_{t-1}\right)+\text { dividend }}{\text { total assets }}$ & https://afx.kwayisi.org/nseng/ \\
\hline The firm size & Total revenue & Log of total revenue & Annual financial statement \\
\hline Growth & $\begin{array}{l}\text { Annual change } \\
\text { in total assets } \\
\text { from year t-1 to } \\
\text { year } t\end{array}$ & $\frac{\text { total }_{\text {assets }_{t}-\text { total assets }}{ }_{t-1}}{\text { total assets }}$ & Annual financial statement \\
\hline
\end{tabular}

*Note: It is necessary to avoid a log of negative numbers

Source: Author

plant and equipment, is the total assets in the year $\mathrm{t}-1$ (consistent with the previous studies, all the variables scaled down by the lagged total assets to minimize heteroskedasticity), and are the parameters to be estimated and is the residuals..

According to X. Li $(2010,8-9)$, the parameters of the ordinary least square regression of the equation (2) are used to estimate the non-discretionary accruals (NDA) in the model as follows:

$$
\begin{aligned}
N D A_{i, t} & =\alpha_{0}\left(\frac{1}{A_{i, t-1}}\right)+\alpha_{1} \frac{\left(\Delta \operatorname{Rev}_{i, t-1}-\Delta \operatorname{Rec} c_{i, t-1}\right)}{A_{i, t-1}} \\
& +\alpha_{2} \frac{P P E_{i, t}}{A_{i, t-1}}
\end{aligned}
$$

Following the discretionary accruals:

$$
D A=\frac{T A_{i, t}}{A_{i, t-1}}-N D A_{i, t}
$$

DA (the discretionary accruals) is the earnings management proxy.

\section{Altman's z-score}

The study adopted the Z-score model for the emerging market (Altman, 2013, 432). It is estimated as follows:

$$
\begin{aligned}
Z & =0.012\left(X_{1}\right)+0.014\left(X_{2}\right)+0.033\left(X_{3}\right)+0.006\left(X_{4}\right) \\
& +0.998\left(X_{5}\right)
\end{aligned}
$$

where:

$$
X_{1}=\frac{\text { current assets }- \text { current liabilities }}{\text { total assets }}
$$

$$
X_{2}=\frac{\text { Retained earnings }}{\text { total assets }} \text {; }
$$

$X_{3}=\frac{\text { Earning before interest and tax }}{\text { total assets }}$; 


$$
\begin{aligned}
& X_{4}=\frac{\text { Book value of equity }}{\text { book value of total debt }} ; \text { and } \\
& X_{5}=\frac{\text { Sales }}{\text { total assets }} .
\end{aligned}
$$

\section{Model specification}

Following the previous studies, the specific model of the study reads:

$$
\begin{aligned}
E M_{c, t} & =\beta_{0}+\beta_{I} P B_{c, t}+\beta_{2} P_{c . t}+\beta_{3} N D T S_{c . t}+\beta_{4} O C F_{c, t}+\beta_{5} S R_{c, t} \\
& +\beta_{6} F S_{c . t}+\beta_{7} G_{c, t}+\mu_{c, t}
\end{aligned}
$$

where:

$E M=$ earnings management, $P B=$ a probability of bankruptcy; $P$ = profitability; NDTS = a non-debt tax shield; $O C F=$ operating cash flows; $S R$ = stock returns; $F S=$ the size of the firm; $G=$ growth; $\beta_{0}=$ the constant term; $\beta_{1}$ to $\beta_{7}=$ the coefficients of the explanatory variables, $c, t$. $=$ the firms and the time; and $\mu=$ the error term.

\section{PRESENTATION OF THE RESULTS AND DISCUSSION}

\section{Descriptive statistics}

Descriptive statistics are presented in Table 2. It shows a deviation from the observed 539 company years because of the lagged years during some variable measurement. For instance, a year is lost from every company when computing growth and stock return $(539-77=462)$. The Table 2 shows that minimum earnings management is -2.0658 , maximum earnings management is 1.5953 , while the mean is -0.0461 . The mean statistics suggest that an earnings understatement is more prevalent. Earnings understatements are the strategy that retains maximum flexibility for future income-increasing attempts. It may help managers change the earnings expectations of financial analysts and investors. It is also a strategy for avoiding a huge tax payment or Government scrutiny (Lisboa, 2019, 72).

The mean score of the probability of bankruptcy is 0.8519 , which suggests that firms might be heading for bankruptcy and need to take a precaution due to a probable insufficiency of capital (Altman, 2013, 426). The maximum value of the probability of bankruptcy is 14.4768 , which is greater than the threshold 3 (Altman, 2013, 432). Stock return has a maximum of 16.67 , a minimum of -0.7346 , and the mean stock return is 0.0382 . The mean operating cash flows are N4.096 billion, the maximum operating cash flows are N154 billion, and the least operating cash flows are minus N104 billion. The mean revenue is N37.9 billion, the least revenue is N5.407 million, and the maximum revenue is $\mathrm{N} 489$ billion.

\section{Correlation}

\begin{tabular}{|c|c|c|c|c|c|}
\hline Variables & Obs. & Means & Std. Dev. & Min. & Max. \\
\hline Earnings management & 447 & -0.0461 & 0.2432 & -2.0658 & 1.5953 \\
\hline Probability of bankruptcy & 539 & 0.8519 & 0.9481 & -0.0123 & 14.4768 \\
\hline Profitability (ROA) & 539 & 0.0186 & 0.1367 & -1.2000 & 0.6858 \\
\hline The non-debt tax shield & 453 & 0.0474 & 0.0917 & 0.0001 & 1.5103 \\
\hline Operating cashflows (N'000) & 539 & $4,096,462$ & $1.55 \mathrm{e}+07$ & $-1.04 \mathrm{e}+08$ & $1.54 \mathrm{e}+08$ \\
\hline Stock returns & 462 & 0.0382 & 0.9071 & -0.7346 & 16.6667 \\
\hline The firm size [Revenue: (N’000)] & 539 & $3.79 e+07$ & $7.45 e+07$ & 5407 & $4.89 e+08$ \\
\hline Growth & 462 & -0.0076 & 0.6501 & -9.4166 & 0.9291 \\
\hline
\end{tabular}

Table 3 presents Spearman's correlation matrix. Profitability $(\mathrm{r}=0.1383, \mathrm{p}=0.0034)$ and growth

Table 2 The descriptive statistics

Source: Author 
Table 3 Spearman's correlation matrix

\begin{tabular}{|c|c|c|c|c|c|c|c|c|}
\hline & 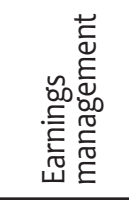 & 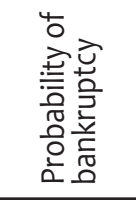 & 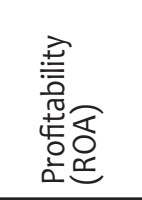 & 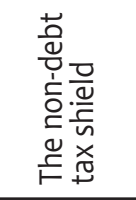 & 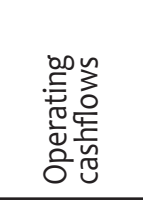 & 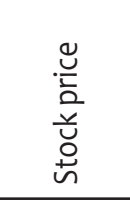 & 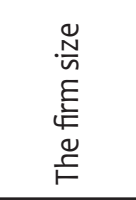 & $\begin{array}{l}\text { 秀 } \\
\text { 인 }\end{array}$ \\
\hline Earnings management & 1.0000 & & & & & & & \\
\hline Probability of bankruptcy & $\begin{array}{c}0.0564 \\
(0.2341)\end{array}$ & 1.0000 & & & & & & \\
\hline Profitability (ROA) & $\begin{array}{c}0.1383 \\
(0.0034)\end{array}$ & $\begin{array}{c}0.3126 \\
(0.0000)\end{array}$ & 1.0000 & & & & & \\
\hline The non-debt tax shield & $\begin{array}{l}-0.2277 \\
(0.000)\end{array}$ & $\begin{array}{c}0.1263 \\
(0.0075)\end{array}$ & $\begin{array}{c}0.1313 \\
(0.0054)\end{array}$ & 1.0000 & & & & \\
\hline Operating cashflows & $\begin{array}{c}-0.2796 \\
(0.0000)\end{array}$ & $\begin{array}{c}0.2003 \\
(0.0000)\end{array}$ & $\begin{array}{c}0.3502 \\
(0.0000)\end{array}$ & $\begin{array}{c}0.1839 \\
(0.0001)\end{array}$ & 1.0000 & & & \\
\hline Stock returns & $\begin{array}{c}-0.0286 \\
(0.5467)\end{array}$ & $\begin{array}{c}0.0219 \\
(0.6435)\end{array}$ & $\begin{array}{c}0.1529 \\
(0.0012)\end{array}$ & $\begin{array}{c}0.0408 \\
(0.3899)\end{array}$ & $\begin{array}{c}0.0771 \\
(0.1037)\end{array}$ & 1.0000 & & \\
\hline The firm size & $\begin{array}{c}0.0732 \\
(0.1221)\end{array}$ & $\begin{array}{c}0.5014 \\
(0.0000)\end{array}$ & $\begin{array}{c}0.2655 \\
(0.0000)\end{array}$ & $\begin{array}{c}0.0799 \\
(0.0915)\end{array}$ & $\begin{array}{c}0.5259 \\
(0.0000)\end{array}$ & $\begin{array}{l}-0.0403 \\
(0.3953)\end{array}$ & 1.0000 & \\
\hline Growth & $\begin{array}{c}0.1391 \\
(0.0032)\end{array}$ & $\begin{array}{c}0.0142 \\
(0.7653)\end{array}$ & $\begin{array}{c}0.3370 \\
(0.0000)\end{array}$ & $\begin{array}{c}0.0826 \\
(0.0809)\end{array}$ & $\begin{array}{c}0.1129 \\
(0.0169)\end{array}$ & $\begin{array}{c}0.1130 \\
(0.0168)\end{array}$ & $\begin{array}{c}0.2220 \\
(0.0000)\end{array}$ & 1.0000 \\
\hline
\end{tabular}

Source: Author

$(\mathrm{r}=0.1391, \mathrm{p}=0.0032)$ are strongly positively correlated with earnings management. The non-debt tax shield $(\mathrm{r}=-0.2277, \mathrm{p}=0.0000)$ and the operating cashflows $(\mathrm{r}=-0.2796, \mathrm{p}=0.0000)$ are strongly negatively correlated with earnings management. The probability of bankruptcy $(r=0.0564, p=0.2341)$ and the size of the firm $(r=0.0732, p=0.1221)$ are weakly positively correlated with earnings management. Growth is weakly negatively correlated with earnings management.

\section{Diagnosis and checks}

In the study, Hausman's test was done to choose between the random effects (RE) model and the fixed effects (FE) model (Table 4). The null hypothesis reads as follows: the RE model is appropriate, whereas the alternative FE model is inappropriate. The test resulted in the p-value $=0.6734$, suggesting that the RE model should be accepted and that the FE model should be rejected. The Breusch-Pagan LM test was also performed so as to choose between the pool ordinary least square (OLS) model and the RE model (Table 4). The null hypothesis reads that the pool OLS is appropriate, whereas the alternative hypothesis reads that the RE model is inappropriate. It results in the $\mathrm{p}$-value $=1.0000$. Thus, the RE model is rejected, whereas the pool OLS model is accepted for the purpose of the analysis. A further diagnosis test was performed to check heteroskedasticity and serial correlation in the data.

The modified Wald test for groupwise heteroskedasticity in the fixed effects regression model was employed to test for heteroskedasticity in the data (Table 4). Ho is homoskedasticity, whereas HA is heteroskedasticity, which results in the p-value = 0.0000 , suggesting heteroskedasticity. Additionally, the Wooldridge test for autocorrelation in panel data was employed to test for the presence of serial correlation in the data (Table 4). Ho is no serial correlation, whereas HA is serial correlation. The p-value is 0.1869 , suggesting no serial correlation in the data. The variance inflation factor (VIF) test (Table 5) showed the highest VIF $=1.40$, the lowest VIF $=1.00$, and the 
Table 4 The diagnostic statistics

The Hausman test: $\mathrm{Chi}^{2}(7)=4.89$; Prob > $\mathrm{Chi}^{2}=0.6734$ suggests that the "Random Effect" is appropriate.

The Breusch-Pagan LM test: Chibar ${ }^{2}(01)=0.00$; Prob $>$ Chibar $^{2}=1.0000$ suggests that the "Pool OLS" is appropriate.

The modified Wald test for groupwise heteroskedasticity in the Fixed Effect regression model 1.

$\mathrm{Chi}^{2}(76)=1.0 \mathrm{e}+06 ;$ Prob $>\mathrm{Chi}^{2}=0.0000$. The data are heteroskedastic.

The Wooldridge panel-data autocorrelation test. $F(1,75)=1.775$; Prob $>F=0.1869$. No serial correlation is found.

Source: Author

mean VIF = 1.19, which depicts no multicollinearity challenges since the obtained VIF values are far below the rule of thumb 7 . Heteroskedasticity challenges prompted employing the heteroskedasticity crosspanel Feasible Generalized Least Squares (FGLS) model [the Panels(heteroskedastic) option which specifies a heteroskedastic error structure with no cross-sectional correlation] rather than the pool OLS model. The FGLS allows estimation in the presence of heteroskedasticity across panels and is suggested by Stata (Stata, 2013).

\section{Analysis of the results and discussion}

The regression result (Table 5) is well-fitted, the p-value $=0.0000$. The probability of bankruptcy was found to have an insignificant negative relationship with earnings management $(-0.0056, p=0.253)$. The result did not support the hypothesis 1 of the study and failed to support the earlier findings that had found a significant positive relationship between the probability of bankruptcy and earnings management (Bisogno \& De Luca, 2015, 47; Dutzi \& Rausch, 2016, 15; Hassanpour \& Ardakani, 2017, 217-218; Lisboa, 2019, 80). Nor did it support N. A. Shabani and S. Sofian $(2018,162)$, who had found a strong negative relationship between earnings smoothing and bankruptcy risk. Probably, the firms only face a temporary illiquidity position and/or that with lowquality earnings management they can decrease their probability of bankruptcy risk.

Profitability (ROA) has a significant positive relationship with earnings management $(0.1890, \mathrm{p}=$ 0.000 ) and supports the hypothesis 2 of the study. It corroborated the studies by A. W. Ghazali et al (2015,
198) and M. A. Abu-Jebbeh and A. Al-Thuneibat (2017, 259), who found a strong positive relationship between profitability and earnings management, but did not support C. P. Cudia and A. L. C. Dela Cruz $(2018,127)$ and H. Anjum et al $(2012,17)$, who found a negative relationship between a profit and earnings management. The result suggests that management may indulge in earnings management by reporting a high profit (low profit) downward (upward) (Beaver, 2002, 466; Ghazali et al, 2015, 198). The reason for earnings management is probably to reflect huge capital employed in business, evade paying huge taxes and avoid Government scrutiny.

A non-debt tax shield has a significant negative influence on earnings management $(-0.7007, p=0.000)$. The result fails to support the hypothesis 3 of the study, and does not support M. Amidu et al (2016, 141), who found a positive relationship between a non-debt tax shield and earnings management. It, however, corroborated the argument by M. Amidu and S. M. Yorke (2017), according to whom there is a negative relationship between a non-debt tax shield and earnings management when management do not engage a sufficient non-debt tax shield instrument for earnings management since it will only be gainful for shareholders, not for themselves (Amidu et al, 2016, 141).

The operating cash flows coefficient is significant and negatively related to earnings management $(-0.0012, \mathrm{p}$ $=0.000)$. The result did not support the hypothesis 4 of the study, and the same contradicted C. P. Cudia and A. L. C. Dela Cruz (2018, 126-127), who found a positive relationship between operating cashflows and earnings management. It, however, corroborated the earlier studies that had shown operating 
Table 5 The FGLS regressions

\begin{tabular}{|c|c|c|c|c|c|}
\hline Earnings management & Coef. & Std. Err. & $\mathrm{t}$ & $\mathrm{p}$ & VIF \\
\hline Probability of bankruptcy & -0.0056 & 0.0049 & -1.14 & 0.253 & 1.22 \\
\hline Profitability (ROA) & 0.1890 & 0.0357 & 5.29 & 0.000 & 1.09 \\
\hline The non-debt tax shield & -0.7007 & 0.0871 & -8.05 & 0.000 & 1.09 \\
\hline Operating cashflows & -0.0012 & 0.0003 & -4.51 & 0.000 & 1.00 \\
\hline Stock return & -0.0098 & 0.0061 & -1.61 & 0.107 & 1.37 \\
\hline The firm size & 0.0052 & 0.0021 & 2.53 & 0.011 & 1.40 \\
\hline Growth & -0.0010 & 0.0064 & -0.16 & 0.873 & 1.17 \\
\hline cons & -0.0858 & 0.0308 & -2.79 & 0.005 & \\
\hline \multicolumn{6}{|c|}{ Wald $\operatorname{chi}^{2}(7)=149.43 ;$ Prob $>\operatorname{chi}^{2}=0.0000$} \\
\hline
\end{tabular}

Source: Author

cashflows had strong negative bearings on earnings management (Andreas, 2017; Jang \& Kim, 2017, 336; Hastuti et al, 2018, 1141). The result suggests that, when operating cashflows are low, managers are likely to initiate earnings management so as to increase their operating cash flow activities, such as accelerating cash collection and probably delaying cash outlays (Andreas, 2017; Jang \& Kim, 2017, 330; El-Diri, 2018, 13). With high operating cashflows, managers may tend to employ the cash policy that delays cash collection or grant a higher credit level (Cudia \& Dela Cruz, 2018, 126-127; El-Diri, 2018, 28).

The stock return coefficient is negatively and insignificantly related to earnings management $(-0.0098, p=0.107)$. The result fails to support S. Sayari et al $(2013,51)$, who found a significantly positive relationship between stock returns and earnings management. The results were all but supportive of the earlier studies that had shown stock returns were negatively significantly related to earnings management (Bansal et al, 2021; Chi \& Gupta, 2009). The negative insignificant result is probably indicative of the fact that the stock exchange is unable to reflect earnings management practice (Al Omush et al, 2019, 20). Perhaps, the stock exchange is in its semi-strong form stage.

The proxy of the size of a firm with a revenue coefficient $\log (0.0052, \mathrm{p}=0.011)$ is positively and significantly related to earnings management. The result supports the hypothesis 6 of the study and corroborates the earlier studies that showed that the firm size had a strong positive relationship with earnings management (Moses, 1987, 358; Hefferman et al, 2008, 13; Gordanlidavaji \& Vakilifard, 2014, 519; Ali et al, 2015, 55; Uwuigbe et al, 2015, 224). The findings suggest that large firms tend to employ earnings management to a greater extend. The reason is probably to avoid being exposed to the risk of Government/regulatory scrutiny (Young, 1999; Dechow et al, 2010, 380; Ali et al, 2015, 48).

Growth has a weak negative influence on earnings management $(-0.0010, p=0.873)$. The result disagrees with the theoretical arguments implying that growing firms will engage themselves in earnings management so as to avoid an unfavorable market reaction, also failing to corroborate C. J. Lee et al (2006) and Kwarbai et al (2019), who found a strong positive relationship between growth and earnings management. Although the negative relationship is weak, it probably portrays the fact that strong growth opportunities overshadow earnings management (Al Saedi, 2018).

\section{CONCLUSION}

In the study, the data from the annual reports and accounts of the 77 nonfinancial firms listed on the NSE for the period from 2013 to 2019 were used in order to examine the determinants of earnings 
management. The result obtained from the sampled firms shows that profitability, the size of a firm, a nondebt tax shield and operating cash flows are the most important determinants of earnings management. Profitability and the firm size have a strong positive impact on earnings management, whereas a nondebt tax shield and operating cash flows have a strong negative influence on earnings management. Managers manipulate earnings probably in order to permanently defer or even evade taxes and avoid Government scrutiny. A likely explanation for the strong negative impact of a non-debt tax shield on earnings management lies in the fact is that using a non-debt tax shield as an earnings management instrument will not benefit managers, but the firm's shareholders instead (Amidu et al, 2016, 141). Management manipulates operating cash flows depending on the level of their needs for cash. The result suggests that earnings management increases with the firm size. In other words, the quality of earnings management decreases as the firm size increases.

The study is only limited to the extent that a sample of only 77 nonfinancial firms listed on the NSE for the period from 2013 to 2019 were analyzed in it. The study, however, contributes to the literature on the determinants of earnings management, having established the strong determinants of earnings management for nonfinancial firms in Nigeria, upon which findings the researcher recommends earnings management related to assets (given the fact that ROA is a function of assets), a non-debt tax shield, and operating cash flows should be minimally employed as an instrument of earnings management since earnings management is likely to reverse or even account for negative consequences in the future and high earnings management portrays a low quality of financial reporting. This will improve the quality of financial reporting, which will attract prospective investors. Future research should enlarge the number of the firms included in the sample, financial firms being included as well. A further study on the determinants of earnings management should also reconsider the impact of the probability of bankruptcy, stock returns and the growth of a firm, which proved to have a weak influence on earnings management.

\section{REFERENCES}

Abu-Jebbeh, M. A., \& Al-Thuneibat, A. (2017). The effect of profitability on earnings management in industrial companies listed in Amman stock exchange. Jordan Journal of Business Administration, 13(2), 259-280.

Al Omush, A. M., Masadeh, W. M., \& Zahran, R. M. (2019). The impact of earnings management on stock returns for listed industrial firms on the Amman stock exchange. Business and Economic Research, 9(3), 1-22. doi.org/10.5296/ ber.v9i3.15011

Al Saedi, A. A. (2018). Earnings management and its relationship with stock returns: An empirical study on a sample of Qatari listed industrial companies. Academy of Accounting and Finance Journal, 22(5), 1-13.

Alareeni, B. (2018). The impact of firm-specific characteristics on earnings management: evidence from gcc countries. International Journal Managerial and Financial Accounting, 10(2), 85-104. doi:10.1504/IJMFA.2018.10012808

Ali, U., Noor, M. A., Khurshid, M. K., \& Mahmood, A. (2015). Impact of firm size on earnings management: A study of textile sector of Pakistan. European Journal of Business $\mathcal{E}$ Management, 7(28), 47-56.

Altman, E. I. (2013). Predicting financial distress of companies: revisiting the Z-Score and ZETA models. In A. R. Bell, C. Brooks, \& M. Prokopczuk (Eds.). Handbook of research methods and applications in empirical finance, chapter 17. (pp. 428-456). Cheltenham, UK: Edward Elgar Publishing Limited.

Amidu, M., \& Yorke, S. M. (2017). Tax avoidance and earnings management of firms in Ghana: Does the funding strategy matter? International Journal of Critical Accounting, 9(3), 238264. doi.org/10.1504/IJCA.2017.088740

Amidu, M., Yorke, S. M., \& Harvey, S. (2016). The effects of financial reporting standards on tax avoidance and earnings quality: A case of an emerging economy. Journal of Accounting \& Finance, 16(2), 129-150.

Andreas, A. (2017). Analysis of operating cash flow to detect real activity manipulation and its effect on market performance. International Journal of Economics \& Financial Issues, 7(1), 524-529.

Anjum, H., Saif, M. I., Malik, Q. A., \& Hassan, S. (2012). Earnings management and firms' profitability: Evidence from Pakistan. European Journal of Economics, Finance $\mathcal{E}$ Administrative Sciences, 47, 13-18. 
Banimahd, B., \& Aliabadi, M. J. (2013). A study on relationship between earnings management and operating cash flows management: Evidence from Tehran stock exchange. Management Science Letters, 3(6), 1677-1682. doi:10.5267/j. msl.2013.05.018

Bansal, M., Ali, A., \& Choudhary, B. (2021). Real earnings management and stock returns: Moderating role of crosssectional effects. Asian Journal of Accounting Research, doi:10.1108/AJAR.11.2020.0107.

Beaver, W. (2002). Perspectives on recent capital market research. The Accounting Review, 77(2), 453-474. doi:10.2308/ accr.2002.77.2.453

Bisogno, M., \& De Luca, R. (2015). Financial distress and earnings manipulation: Evidence from Italian SMEs. Journal of Accounting and Finance, 4(1), 42-51.

Chalak, S. L., \& Mohammadnezhad, S. (2012). Investigation of the relationship between earnings management and free cash flows in firms with high free cash flows and low growth listed in Tehran Securities Exchange. World Applied Sciences Journal, 20(3), 429-437. doi:10.5829/idosi. wasj.2012.20.03.2372

Chi, J. D., \& Gupta, M. (2009). Overvaluation and earnings management. Journal of Banking and Finance, 33(9), 1652-1663.

Clemente-Almendros, J. A., \& Sogorb-Mira, F. (2018). Costs of debt, tax benefits and a new measure of non-debt tax shields: Examining debt conservatism in Spanish listed firms. Spanish Accounting Review, 21(2), 162-175. doi.org/10.1016/j.rcsar.2018.05.001

Cudia, C. P., \& Dela Cruz, A. L. C. (2018). Determinants of earnings management choice among publicly listed industrial firms in the Philippines. DLSU Business $\mathcal{E}$ Economic Review, 27(2), 119-129.

Darmawan, I. P. E., Sutrisno, T., \& Mardiati, E. (2019). Accrual earnings management and real earnings management: Increase or destroy firm value? International Journal of Multicultural \& Multireligious Understanding, 6(2), 8-19. doi.org/10.18415/ijmmu.v6i2.551

Dechow, P. M., Sloan, R. G., Sweeney, A. P. (1995). Detecting earnings management. The Accounting Review, 70(2), 193225 .
Dechow, P., Ge, W., \& Schrand, C. (2010). Understanding earnings quality: A review of the proxies, their determinants, and their consequences. Journal of Accounting \& Economics, 50(2-3), 344-401. doi.org/10.1016/j.jacceco.2010.09.001

Desai, M. A., \& Dharmapala, D. (2009) Earnings management, corporate tax shelters, and book-tax alignment. National Tax Journal, 62(1), 169-186. doi.org/10.17310/ntj.2009.1.08

Dutzi, A., \& Rausch, B. (2016). Earnings management before bankruptcy: A review of the literature. Journal of Accounting \& Auditing: Research and Practice, 2016, 1-12. doi:10.5171/2016.245891

Dyreng, S. D., Hanlon, M., \& Maydew, E. L. (2010). The effects of executives on corporate tax avoidance. The Accounting Review, 85(4), 1163-1189. doi.org/10.2308/accr.2010.85.4.1163

El Diri, M. (2018). Introduction to earnings management. Cham, Switzerland: Springer International Publishing,

Emudainohwo, O. B. (2020). IFRS and stock exchange development in sub-Saharan Africa: A logistic model. Investment Management and Financial Innovations, 17(3), 397407. doi:10.21511/imfi.17(3).2020.30

Financial Accounting Standards Board (FASB). (2008). Statement of Financial Accounting Concepts No. 2: Qualitative Characteristics of Accounting Information.

Financial Accounting Standards Board (IFRS 10). (2011). Consolidated Financial Statements. Retrieved January 1, 2020, from https://www.iasplus.com/en/standards/ifrs/ifrs10

Ghazali, A. W., Shafie, N. A., \& Sanusi, Z. M. (2015). Earnings management: An analysis of opportunistic behaviour, monitoring mechanism and financial distress. Procedia Economics and Finance, 28, 190-201. doi:10.1016/S22125671(15)01100-4

Gordanlidavaji, J., \& Vakilifard, H. (2014). The effect of firm size and growth opportunity on accounting discretion and its relationship with future stock return (management opportunism test). Journal of Natural \& Social Sciences, 3(3), 511-521.

Harbula, P. (2001). The free cash-flow theory versus financial constraints: investments, corporate governance and soft budgeting problems. Acta Oeconomica, 51(4), 489-512. doi:10.1556/AOecon.51.2000-2001.4.3 
Hassanpour, S., \& Ardakani, M. N. (2017). The effect of prebankruptcy financial distress on earnings management tool. International Review of Management \& Marketing, 7(3), 213-219.

Hastuti, C. S. F., Arfan, M., \& Diantimala, Y. (2018). The influence of free cash flow and operating cash flow on earnings management of firms listed in the Indonesian Stock Exchange. International Journal of Academic Research in Business \& Social Sciences, 8(9), 1133-1146. doi:10.6007/ijarbss/ v8-i9/4686

Hefferman, S., Xiaoqing, M. F., \& Xiaolan, F. (2008). Financial innovation in the UK. Unpublished Working paper No 4.

Jang, B. G., \& Kim, J. W. (2017). Effect of key financial indicators on earning management in Korea's ready mixed concrete industry. The Journal of Applied Business Study, 33(2), 329-342. doi.org/10.19030/jabr.v33i2.9905

Kumar, P. R., \& Ravi, V. (2007). Bankruptcy prediction in banks and firms via statistical and intelligent techniquesare view. European Journal of Operational Research, 180(1), 1-28. doi.org/10.1016/j.ejor.2006.08.043

Kwarbai, J. D., Akintoye, R. I., Adegbie, F. F., \& Nwaobia, A. N. (2019). Growth opportunities and earnings quality from emerging economies. Preprint from Preprints.org, 23 Aug 2019, doi:10.20944/preprints201908.0236.v1.

Lee, C. J., Li, L. Y., \& Yue, H. (2006). Performance, growth and earnings management. Review of Accounting Studies, 11(2-3), 305-334. doi.org/10.1007/s11142-006-9009-9

Li, X. (2010). Real earnings management and subsequent stock returns. Retrieved March 10, 2021, from http://dx.doi. org/10.2139/ssrn.1679832

Lisboa, I. (2019). Do firms in revitalization engage in earnings management: The Portuguese case. Portuguese Journal of Finance, Management \& Accounting, 5(9), 69-88.

Lusi, D., \& Swastika, T. (2013). Corporate governance, firm size, and earning management: Evidence in Indonesia stock exchange. Journal of Business and Management, 10(4), 77-82.

McNichols, M. F. (2000). Research design issues in earnings management studies. Journal of Accounting and Public Policy, 19(4-5), 313-345. doi.org/10.1016/S0278-4254(00)00018-1
Moses, O. D. (1987). Income smoothing and incentives: empirical tests using accounting changes. The Accounting Review, 62(2), 358-377.

Nuryaman, N. (2013). The influence of earnings management on stock return and the role of audit quality as a moderating variable. International Journal of Trade, Economics and Finance, 4(2), 73-78. doi:10.7763/ijtef.2013.v4.263

Osemene, O. F., Adeyele, J. S., \& Adinnu, P. (2018). The impact of the ownership structure and board characteristics on earnings management in Nigeria's listed deposit money banks. Economic Horizons, 20(3), 209-220. doi:10.5937/ ekonhor1803215O

Rego, S. O., \& Wilson, R. (2012). Equity risk incentives and corporate tax aggressiveness. Journal of Accounting Research, 50(3), 775-810. doi.org/10.1111/j.1475-679X.2012.00438.x

Sayari, S., Mraihi, F., Finet, A., \& Omri, A. (2013). The impact of earnings management on stock returns: The case of Tunisian firms. Global Journal of Management and Business Research Finance, 13(10), 50-65.

Shabani, N. A., \& Sofian, S. (2018). Earnings smoothing and bankruptcy risk in liquidating private firms. Asian Journal of Finance and Accounting, 10(1), 162-177. doi:10.5296/ajfa. v10i1.12904

Uwuigbe, U., Ranti, U. O., \& Bernard, O. (2015). Assessment of the effects of firms' characteristics on earnings management of listed firms in Nigeria. Asian Economic \& Financial Review, 5(2), 218-228. doi:10.18488/journal.aefr/2015.5.2/102.2.218.228

World Economic Forum. (2020). Nigeria. Retrieved May 11, 2020, from https://www.weforum.org/agenda/ archive/ nigeria/

Young, S. (1999). Systematic measurement error in the estimation of discretionary accruals: An evaluation of alternative modelling procedures. Journal of Business Finance and Accounting, 26(7/8). 833-862. doi.org/10.1111/14685957.00277 


\section{Received on $6^{\text {th }}$ January 2021, after revision, accepted for publication on $12^{\text {th }}$ July 2021 \\ Published online on $2^{\text {nd }}$ August 2021}

Ochuko Benedict Emudainohwo holds a Ph.D. of Philosophy Degree in Accountancy from UK. He is a lecturer at the Delta State University, Abraka, Nigeria. His research interest includes Strategic Financial Management and Performance Management. He is an Associate Chartered Accountant. 


\title{
ODREDNICE UPRAVLJANJA ZARADAMA: STUDIJA O NEFINANSIJSKIM DRUŠTVIMA U NIGERIJI
}

\author{
Ochuko Benedict Emudainohwo \\ Delta State University, Faculty of the Social Sciences, Department of Accounting and Finance, \\ Abraka, Nigeria
}

U postojećoj literaturi, podsticaji menadžera se dovode u vezu sa upravljanjem zaradama, što je na globalnom planu objasnilo kolaps nekih poznatih uglednih firmi, jer oslikava nizak kvalitet finansijskog izveštavanja. U ovoj studiji su korišćeni podaci dobijeni iz 77 nefinansijskih firmi koje se kotiraju na nigerijskoj Berzi, a odnose se na period 2013-2019, u cilju ispitivanja odrednica upravljanja zaradama. Dobijeni rezultati ukazuju na dokaze koji upućuju na podsticaje za upravljanje zaradama. Profitabilnost (ROA) i veličina firme ostvaruju snažan pozitivan uticaj na upravljanje zaradama, dok nedužnički poreski štit i operativni tokovi novca snažno negativno utiču na upravljanje zaradama. U studiji se sugeriše, eksternim interesnim grupama, da posmatraju one faktore firme koji utiču na aktivu, nedužnički poreski štit, operativne tokove novca (kao što je ubrzavanje/odlaganje gotovinskih primitaka/plaćanje kroz prodaju na kredit i odobravanje popusta), a kada je u pitanju firma koja se širi, na faktore koji utiču na upravljanje zaradama. Menadžment bi trebalo da, u najmanjoj mogućoj meri, koristi gore navedene faktore kao instrument za upravljanje zaradama.

Ključne reči: upravljanje zaradama, nefinansijske firme, nigerijska Berza, povraćaji na akcije

JEL Classification: G14, M41 